\title{
Seropositivity for HIV and the development of AIDS or AIDS related condition: three year follow up of the San Francisco General Hospital cohort
}

\author{
ANDREW R MOSS, PETER BACCHETTI, DENNIS OSMOND, WALTER KRAMPF, \\ RICHARD E CHAISSON, DANIEL STITES, JUDITH WILBER, JEAN-PIERRE ALLAIN, \\ JAMES CARLSON
}

\begin{abstract}
The three year actuarial progression rate to the acquired immune deficiency syndrome (AIDS) in a cohort of men in San Francisco who were seropositive for the human immunodeficiency virus (HIV) was $22 \%$. An additional 26 (19\%) developed AIDS related conditions. $\beta_{2}$ Microglobulin concentration, packed cell volume, HIV p24 antigenaemia, and the proportion and number of T4 lymphocytes each independently predicted progression to AIDS. $\beta_{2}$ Microglobulin was the most powerful predictor. The 111 subjects tested who were normal by all predictors $(40 \%)$ had a three year progression rate of $7 \%$, and the 68 subjects who were abnormal by two or more predictors $(24 \%)$ had a progression rate of $57 \%$. Two thirds of all men who progressed to AIDS were in the last group. The median T4 lymphocyte count in subjects who did not progress to AIDS
\end{abstract}

University of California, San Francisco, and San Francisco General Hospital ANDREW R MOSS, PHD, associate professor, epidemiology and international health

PETER BACCHETTI, PHD, assistant professor, biostatistics

DENNIS OSMOND, MA, associate specialist, epidemiology and international health

WALTER KRAMPF, MD, research associate, epidemiology and international health

RICHARD E CHAISSON, MD, assistant clinical professor, medicine

DANIEL STITES, MD

San Francisco Department of Public Health

JUDITH WILBER, PHD, virologist

Abbott Laboratories, Abbott Park, Illinois

JEAN-PIERRE ALLAIN, MD, PHD, manager, medical research, hepatitis/AIDS diagnostic products

University of California, Davis

JAMES CARLSON, PHD, associate professor, pathology

Correspondence and requests for reprints to: Andrew $\mathrm{R}$ Moss, UCSF Department of Epidemiology and International Health, San Francisco General Hospital, 995 Potrero Avenue, Ward 84, San Francisco CA 94110. fell from $626 \times 10^{6}$ to $327 \times 10^{6} / 1$. HIV p24 antigenaemia developed in $7 \%$ of the subjects per year. The proportion who were abnormal by two or more predictive variables rose to $41 \%$. At three years an estimated two thirds of the seropositive subjects showed clinical AIDS, an AIDS related condition, or laboratory results that were highly predictive of AIDS.

It is concluded from the observed rates and the distribution of predictive variables at three years that half of the men who were seropositive for HIV will develop AIDS by six years after the start of the study, and three quarters will develop AIDS or an AIDS related condition.

\section{Introduction}

The acquired immune deficiency syndrome (AIDS) was first reported in the United States in $1981,{ }^{1}$ and its association with infection by the human immunodeficiency virus (HIV) was shown in 1983-4. ${ }^{23}$ But the likelihood of a person who is infected with HIV developing clinical AIDS has not been made clear. Goedert et al recently showed three year actuarial progression rates of $34 \%$ and $17 \%$ respectively in cohorts of homosexual men who were recruited in New York and Washington, DC, ${ }^{4}$ whereas Polk et al reported a crude 15 month progression rate of only $3.2 \%$ in the Multicenter AIDS Cohort Study. ${ }^{5}$ In the San Francisco City Clinic cohort of 63 men with long term infection $19(30 \%)$ developed AIDS at a median of five years from seroconversion (N Hessol et al, presented at the third international conference on AIDS, Washington, DC, June 1987). One cohort of haemophiliacs shows an $18 \%$ actuarial progression rate at six years after seroconversion. ${ }^{6}$

We report on progression to AIDS in a cohort of homosexual men who were recruited in San Francisco.

\section{Methods}

A total of 462 homosexual men were initially chosen for a case-control study of AIDS. ${ }^{6}$ Group 1 comprised randomly selected neighbourhood 
control subjects, group 2 control subjects from clinics for sexually transmitted diseases, and group 3 sexual partners of patients with AIDS. Control subjects were excluded if they reported having oral candidiasis, herpes zoster, persistent lymphadenopathy, or any two of persistent unexplained fevers, night sweats, shortness of breath, or weight loss. For this study all were seen at the AIDS clinic at San Francisco General Hospital in 1983-4, median date May 1984, and then at 12 month intervals.

HIV serology was performed at the University of California, Davis, by enzyme immunoassay and confirmed by Western blot. ${ }^{7}$ Two subjects who were positive on Western blot for p24 antigen only were excluded. HIV p24 antigen was detected using the enzyme immunoassay of Abbott Laboratories. ${ }^{8} \mathrm{~T}$ lymphocyte subsets were determined by direct immuno- fluorescence using monoclonal antibodies and flow cytometry. ${ }^{9}$ Serum concentrations of $\beta_{2}$ microglobulin were measured using the Phazazym $B_{2}$ Micro Test competitive enzyme immunoassay (Pharmacia Diagnostics, Piscataway, NJ).

Lymphadenopathy on physical examination was determined by the presence of two or more extrainguinal sites of at least $1.0 \mathrm{~cm}$. An AIDS related condition (ARC) was defined as one or more of the following in a seropositive man: thrush, hairy leucoplakia, unexplained weight loss of over $4.5 \mathrm{~kg}$, or fevers, night sweats, or diarrhoea persisting for more than a week. ARC2 was defined as ARC and fewer than 400 T4 lymphocytes $\times 10^{6} / 1$. (ARC2 is similar to Walter Reed stage $5 .{ }^{10}$ )

Progression to AIDS (Centers for Disease Control revised surveillance

TABLE I-Two year actuarial progression rates to AIDS, relative hazards from the proportional hazards model, and relative hazards adjusted for number of $T 4$ lymphocytes by selected clinical values at first follow up

\begin{tabular}{|c|c|c|c|c|}
\hline & $\begin{array}{l}\text { No who progressed } \\
\text { to AIDS/total No }\end{array}$ & $\begin{array}{l}\text { Two year actuarial } \\
\text { progression rate }(\%)\end{array}$ & Relative hazard & $\begin{array}{l}\text { Relative hazard adjusted for } \\
\text { No of T4 lymphocytes }\end{array}$ \\
\hline Total cohort & $31 / 219$ & 19 & & \\
\hline \multicolumn{5}{|l|}{ Lymphadenopathy at follow up } \\
\hline Yes & $17 / 118$ & 20 & $1 \cdot 0$ & $0 \cdot 8$ \\
\hline No & $14 / 100$ & 19 & $1 \cdot 0$ & \\
\hline \multicolumn{5}{|l|}{ Lymphadenopathy for one year } \\
\hline Yes & $5 / 30$ & 22 & $1 \cdot 3$ & 1.5 \\
\hline No & $22 / 151$ & 21 & $1 \cdot 0$ & \\
\hline \multicolumn{5}{|l|}{ Shingles } \\
\hline Yes & $2 / 8$ & 25 & $1 \cdot 8$ & $2 \cdot 2$ \\
\hline No & $29 / 210$ & 19 & $1 \cdot 0$ & \\
\hline \multicolumn{5}{|l|}{ Thrush } \\
\hline Yes & $7 / 20$ & 39 & $2 \cdot 9^{\star}$ & $2 \cdot 0$ \\
\hline No & $24 / 195$ & 17 & $1 \cdot 0$ & \\
\hline \multicolumn{5}{|l|}{ Hairy leucoplakia } \\
\hline Yes & $3 / 9$ & 42 & $3 \cdot 4^{\star}$ & $3 \cdot 9^{\star}$ \\
\hline No & $28 / 206$ & 18 & $1 \cdot 0$ & \\
\hline \multicolumn{5}{|c|}{ Symptoms (night sweats, fever, or weight loss) } \\
\hline Yes & $4 / 4$ & 100 & $21 \cdot 9 \star \star$ & $8 \cdot 7 \star \star$ \\
\hline No & $27 / 214$ & 18 & $1 \cdot 0$ & \\
\hline \multicolumn{5}{|c|}{ ARC (thrush or hairy leucoplakia or symptoms) } \\
\hline Yes & $10 / 26$ & 44 & $3 \cdot 9 \star \star$ & $2 \cdot 8^{\star}$ \\
\hline No & $21 / 192$ & 16 & $1 \cdot 0$ & \\
\hline \multicolumn{5}{|c|}{ ARC $2\left(\right.$ ARC and $\leqslant 400 \mathrm{~T} 4$ lymphocytes $\left.\times 10^{6} / 1\right)$} \\
\hline Yes & $8 / 10$ & 88 & $12 \cdot 2^{\star \star}$ & $3 \cdot 9 \star \star$ \\
\hline No & $23 / 209$ & 15 & $1 \cdot 0$ & \\
\hline
\end{tabular}

${ }^{\star \star} \mathrm{p}<0.01 ;{ }^{\star} \mathrm{p}<0.05$

Note: Not all tests were carried out on all subjects so totals may not add up to 219 .
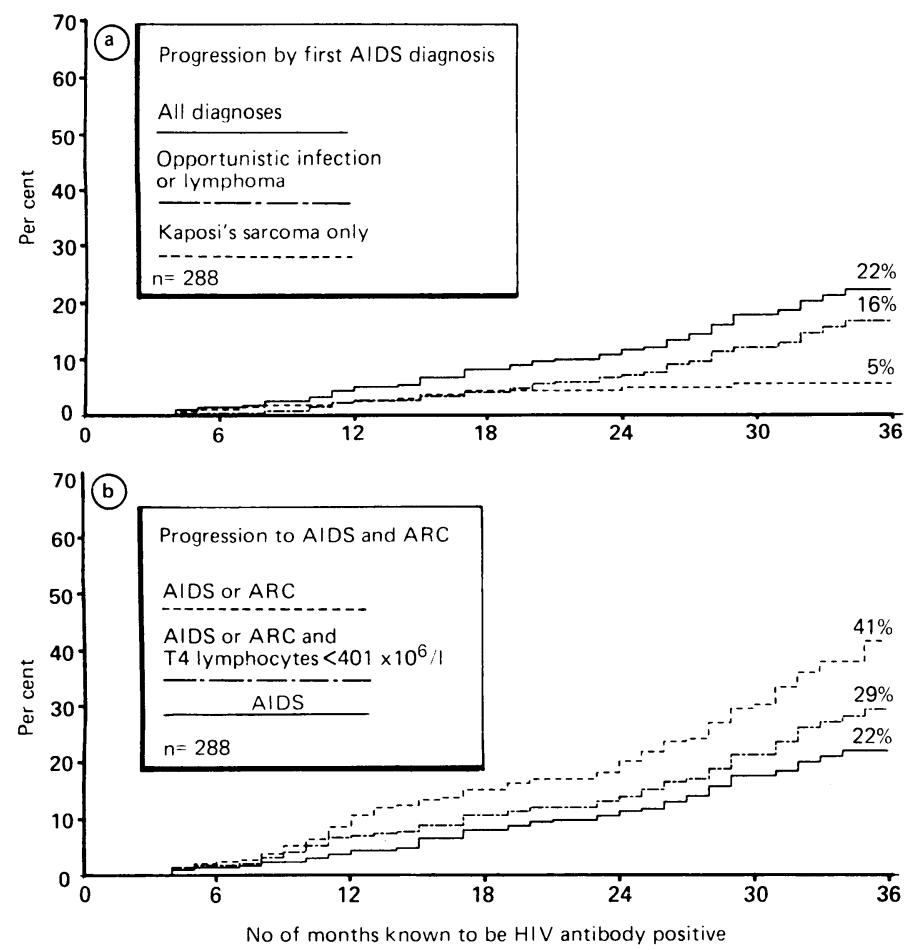

FIG 1-Progression curves to AIDS and AIDS related conditions (ARC) in 288 HIV seropositive men. (a) Progression to AIDS by first AIDS diagnosis. (b) Progression to AIDS, AIDS or ARC, and AIDS or ARC and $\leqslant 400$ T4 lymphocytes $\times 10^{6} / 1$. definition, $1985^{11}$ ) was established by diagnosis at the clinic, by a confirmed report to the Centers for Disease Control, or, for subjects who were not from California, by a death certificate or the report of a physician. At the first follow up $237(82 \%)$ eligible subjects were examined and at the second follow up $183(81 \%$ of those who continued in the study). The third cycle of examinations is still being carried out. A further $19(7 \%)$ subjects have consented to continued morbidity follow up by a telephone interview with confirmation by their physician.

Subjects who did not have AIDS at a clinic visit or telephone interview were considered to be free of AIDS through June 1986. Subjects who did not progress towards developing AIDS and did not have a physical examination after June 1986 were assumed to be free of ARC if free of AIDS. This assumption underestimates ARC. One man in whom Kaposi's sarcoma was diagnosed immediately on entering the study was excluded from the current analysis.

Loss to follow up may cause bias on observed laboratory values over time; thus figures 3 and 4 show both raw and baseline adjusted medians and proportions. The baseline adjusted value in each case is the change from baseline in those seen at follow up applied to the baseline value for all subjects.

Since the follow up ranged from 19 to 44 months actuarial progression rates were calculated using the product limit method, and progression data were analysed using the proportional hazards model. ${ }^{12}$ Both methods take the differing amounts of follow up into account.

\section{Results}

\section{SEROPOSITIVITY AND ANTIGENAEMIA}

Of 462 men in the cohort, 288 were seropositive for HIV at entry $(62 \%)$, including 57 of 145 (39\%) in group 1, 106 of $149(71 \%)$ in group 2, and 125 of $168(74 \%)$ in group 3 . Of 281 men who were HIV antibody positive, 46 were antigenaemic for HIV p24 (16\%), and 210 had antibody to p24 (75\%). Seven subjects had both p 24 antigen and antibody, and 32 had neither. 


\section{PROGRESSION TO AIDS AND ARC}

Fifty of 288 seropositive subjects progressed to clinical AIDS during follow up (17\%). The rate of progression increased over the period of follow up. Actuarial progression rates with $95 \%$ confidence intervals were $5 \%$ ( 2 to 7 ) at one year, $11 \%$ (8 to 15$)$ at two years, and $22 \%$ (16 to 30$)$ at three years (fig la). Fifteen men were first diagnosed with Kaposi's sarcoma only, two with lymphoma, 32 with opportunistic infection, primarily Pneumocystis carinii pneumonia, and one with both Kaposi's sarcoma and $P$ carinii pneumonia. The incidence of Kaposi's sarcoma decreased: seven of 14, six of 18 , and one of 17 progressors were first diagnosed with Kaposi's sarcoma in three successive 12 month periods (fig $1 a$ ). (In one man it was diagnosed at 41 months.)

The actuarial progression rate to AIDS or ARC at three years was $41 \%$. The actuarial progression rate to AIDS or ARC2 was $34 \%$ (fig $1 b$ ).

\section{PROGRESSION TO AIDS FROM ARC}

We examined progression to AIDS from ARC at the first follow up visit because most subjects were screened for AIDS related conditions at baseline. Thrush, hairy leucopenia, and systemic symptoms all predicted progression to AIDS, but shingles and lymphadenopathy (at first follow up or lasting for one year) did not (table I). Twenty six of 217 men had ARC, as defined, and 11 of 26 progressed to AIDS over the remaining two years (actuarial rate $44 \%$ ). Ten men had ARC2 at first follow up and eight of 10 progressed to AIDS (actuarial rate $88 \%$ ). (The 24 month actuarial rate for men with T4 lymphocytes $\leqslant 400 \times 10^{6} / 1$ but without ARC was $29 \%$.) Six men with ARC were also HIV p24 antigenaemic. Four progressed to AIDS (actuarial rate $67 \%$ ).

\section{PREDICTORS OF PROGRESSION TO AIDS}

Progression to AIDS was strongly associated with the absolute number and proportion of T4 lymphocytes. Progression was also strongly associated with HIV p24 antigenaemia (table II, fig $2 a, b$ ). Presence of p24 antigen was closely comparable with $\mathrm{T} 4 \leqslant 400 \times 10^{6} / 1$ as a predictive variable $\left(\chi^{2}=24.8\right.$ and 24.7 respectively). The two predictors were largely independent, only 15 men having both $T 4 \leqslant 400 \times 10^{6} / 1$ and p24 antigen. p24 antigen remained a strong predictor after adjustment for T4 lymphocytes.

There was a weaker association with loss of antibody to p24 antigen (table II), which was not significant when controlled for presence of antigen (relative hazard $=1 \cdot 5, \mathrm{p}=0 \cdot 27$ ). Thus antigenaemia was the better predictor. Antigen quantity was not statistically associated with progression, though five of seven subjects with p24>350 mg/l progressed to AIDS

Progression was strongly associated with the $\beta_{2}$ microglobulin concentration, which was a better predictor of progression than T4 lymphocytes when both were expressed as trichotomies $\left(\chi^{2}=42 \cdot 2\right.$ and $31 \cdot 3$, respectively), and remained a strong predictor after adjustment for $\mathrm{T} 4$ lymphocytes (table II and fig $2 a, c$ )

Progression was also associated with an increased number of suppressor/ cytotoxic (T8) lymphocytes, with T4/T8 ratio, with increased IgA but not IgG or IgM, with anaemia (measured by haemoglobin, packed cell volume, or red cell count) and with erythrocyte sedimentation rate, and these associations persisted after adjustment for T4 lymphocytes (table II). There was no association with platelet count after adjustment for T4 lymphocytes, with lymphadenopathy at baseline, or with white cell count.

In a stepwise multivariate analysis of progression we found independent predictive effects associated with $(i) \beta_{2}$ microglobulin concentration at entry ( $>5.0$ and $>3.0 \mathrm{mg} / \mathrm{l})$; (ii) packed cell volume $<40 ;$ (iii) p24 antigenaemia;
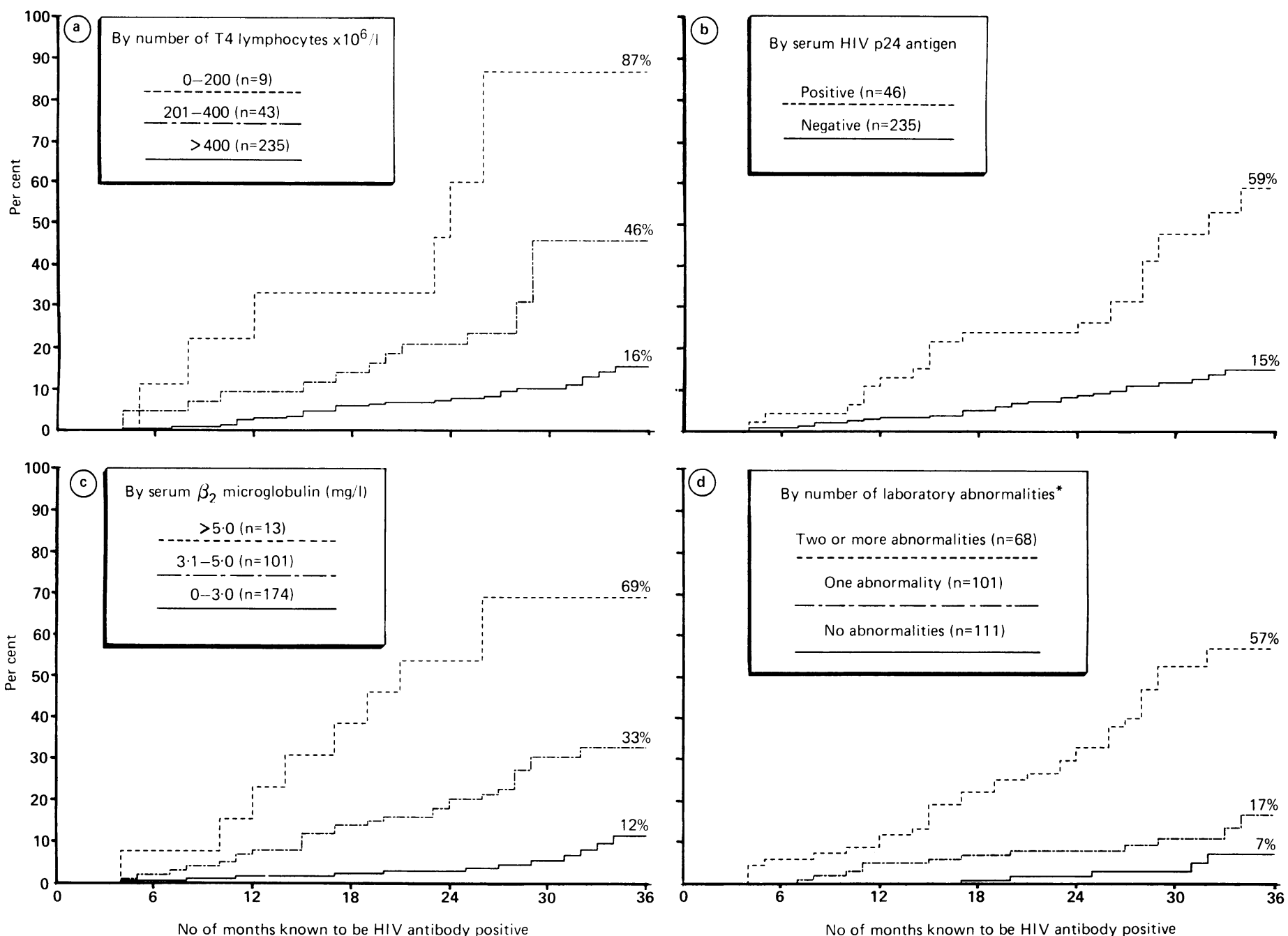

FIG 2-Progression curves to AIDS by laboratory results at baseline examination. (a) By number of T4 lymphocytes $\times 10^{6} / 1$. $(b)$ By presence or absence of $\mathrm{HIV}$ p 24 antigen. (c) By serum $\beta_{2}$ microglobulin concentration. (d) By number of laboratory abnormalities. ${ }^{\star}\left(\beta_{2}\right.$ Microglobulin $>3$ mg/l; packed cell volume $<40$; HIV p24 antigen present; T4 lymphocytes $<25 \%$ of all lymphocytes; T4 lymphocytes $\leqslant 200 \times 10^{6} / 1$.) 
(iv) proportion of T4 lymphocytes $<25 \%$; and (v) absolute number of T4 lymphocytes $\leqslant 200 \times 10^{6} / \mathrm{l}$ (table III).

Of 280 subjects who were seropositive, $111(40 \%)$ were normal on all five predictive variables at baseline, $101(36 \%)$ were abnormal on one variable, $39(14 \%)$ on two, $20(7 \%)$ on three, and nine $(3 \%)$ on four. Among 170 seronegative men, $149(88 \%)$ had no abnormalities, $20(12 \%)$ had one abnormality, and one (1\%) was abnormal on two variables. Crude progression rates for seropositive subjects in the five categories were $5 \%, 12 \%$, with T4 lymphocytes $\leqslant 400 \times 10^{6} / 1$ rose from $18 \%$ to $49 \%$, and the proportion with T4 lymphocytes $\leqslant 200 \times 10^{6} / 1$ from $3 \%$ to $18 \%$ (fig $4 a$ ). The proportion with detectable p 24 antigen rose from $16 \%$ to $20 \%$ (fig $4 b$ ), and men became antigenaemic at $5 \%, 7 \%$, and $9 \%$ per year in the three years respectively $(7 \%$ a year overall). The proportion with $\beta_{2}$ microglobulin $>5.0 \mathrm{mg} / 1$ rose from $5 \%$ to $9 \%$ (fig $4 c$ ), the proportion with less than $25 \%$ T4 lymphocytes rose $29 \%$ to $42 \%$ (fig $4 d$ ), and the proportion with a packed cell volume of $<40$ rose from $9 \%$ to $15 \%$ (data not shown). The proportion in the abnormal

TABLE II-Three year actuarial progression rates to AIDS, relative hazards from the proportional hazards model, and relative hazards adjusted for number of T4 lymphocytes by laboratory values at baseline

\begin{tabular}{|c|c|c|c|c|}
\hline Variable & $\begin{array}{l}\text { No who progressed } \\
\text { to AIDS/total No }\end{array}$ & $\begin{array}{l}\text { Three year actuarial } \\
\text { progression rate }(\%)\end{array}$ & Relative hazard & $\begin{array}{l}\text { Relative hazard adjusted for } \\
\text { No of T4 lymphocytes }\end{array}$ \\
\hline Total cohort & $50 / 288$ & 22 & & \\
\hline \multicolumn{5}{|l|}{ T4 lymphocytes $\left(\times 10^{6} / 1\right)$} \\
\hline$\leqslant 200$ & $7 / 9$ & 87 & $13 \cdot 4^{\star \star}$ & \\
\hline $201-400$ & $15 / 43$ & 46 & $3 \cdot 6^{\star \star}$ & \\
\hline$>400$ & $28 / 235$ & 16 & $1 \cdot 0$ & \\
\hline \multicolumn{5}{|c|}{ Proportion of T4 lymphocytes (\%) } \\
\hline$<25$ & $31 / 83$ & 48 & $5 \cdot 1 \star \star$ & $3 \cdot 5 \star \star$ \\
\hline$\geqslant 25$ & $19 / 204$ & 12 & $1 \cdot 0$ & \\
\hline \multicolumn{5}{|l|}{ T8 lymphocytes $\left(\times 10^{6} / 1\right)$} \\
\hline$\geqslant 1000$ & $21 / 89$ & 27 & $1 \cdot 7$ & $2 \cdot 0^{\star}$ \\
\hline$<1000$ & $29 / 198$ & 20 & $1 \cdot 0$ & \\
\hline \multicolumn{5}{|l|}{$\mathrm{T} 4 / \mathrm{T} 8$ ratio } \\
\hline$<0 \cdot 4$ & $12 / 19$ & 80 & $11 \cdot 9 \star \star \star$ & $5 \cdot 7 \star \star$ \\
\hline $0 \cdot 4-0 \cdot 6$ & $23 / 82$ & 33 & $3 \cdot 7^{\star \star}$ & $3 \cdot 2^{\star \star}$ \\
\hline$>0 \cdot 6$ & $15 / 186$ & 11 & $1 \cdot 0$ & \\
\hline \multicolumn{5}{|l|}{ Tlymphocytes $\left(\times 10^{6} / 1\right)$} \\
\hline$<600$ & $8 / 16$ & 54 & $4 \cdot 4 \star \star$ & 0.9 \\
\hline$\geqslant 600$ & $42 / 271$ & 20 & $1 \cdot 0$ & \\
\hline \multicolumn{5}{|l|}{ Total lymphocytes $\left(\times 10^{6} / 1\right)$} \\
\hline$\leqslant 900$ & $6 / 9$ & 70 & $6 \cdot 4^{\star \star}$ & $1 \cdot 1$ \\
\hline$>900$ & $44 / 279$ & 20 & $1 \cdot 0$ & \\
\hline \multicolumn{5}{|l|}{ HIV p 24 antigen } \\
\hline Yes & $22 / 46$ & 59 & $4 \cdot 6^{\star \star}$ & $3 \cdot 9 \star \star$ \\
\hline No & $28 / 235$ & 15 & $1 \cdot 0$ & \\
\hline \multicolumn{5}{|l|}{ Anti-HIV p24 } \\
\hline No & $25 / 70$ & 43 & $3 \cdot 2 \star \star$ & $3 \cdot 1 \star \star$ \\
\hline Yes & $25 / 210$ & 16 & $1 \cdot 0$ & \\
\hline \multicolumn{5}{|l|}{$\beta_{2}$ Microglobulin $(\mathrm{mg} / \mathrm{l})$} \\
\hline$>5 \cdot 0$ & $10 / 13$ & 69 & $16 \cdot 9 \star \star$ & $11 \cdot 5^{\star \star}$ \\
\hline $3 \cdot 1-5 \cdot 0$ & $28 / 101$ & 33 & $4 \cdot 5 \star \star$ & $3 \cdot 7 \star \star$ \\
\hline$\leqslant 3 \cdot 0$ & $12 / 174$ & 12 & $1 \cdot 0$ & \\
\hline \multicolumn{5}{|l|}{ Haemoglobin (g/dl) } \\
\hline$<13.5$ & $7 / 15$ & 50 & $4 \cdot 5^{\star \star}$ & $3 \cdot 4 \star \star$ \\
\hline$\geqslant 13.5$ & $43 / 273$ & 21 & $1 \cdot 0$ & \\
\hline \multicolumn{5}{|l|}{ Packed cell volume } \\
\hline$<40$ & $12 / 25$ & 54 & $4 \cdot 3 \star \star$ & $3 \cdot 7 \star \star$ \\
\hline \multirow{2}{*}{\multicolumn{5}{|c|}{ White blood cells $\left(\times 10^{9} / 1\right)$}} \\
\hline & & & & \\
\hline$<5 \cdot 0$ & 267110 & 34 & $2 \cdot 0^{\star}$ & $1 \cdot 2$ \\
\hline$\geqslant 5 \cdot 0$ & $24 / 178$ & 16 & $1 \cdot 0$ & \\
\hline \multicolumn{5}{|l|}{ Red blood cells $\left(\times 10^{12} / 1\right)$} \\
\hline$<4.50$ & $15 / 41$ & 50 & $3 \cdot 0^{\star \star}$ & $2 \cdot 5^{\star \star}$ \\
\hline$\geqslant 4.50$ & $35 / 247$ & 18 & $1 \cdot 0$ & \\
\hline \multicolumn{5}{|c|}{ Erythrocyte sedimentation rate ( $\mathrm{mm}$ in 1 st hour) } \\
\hline$\geqslant 15$ & $20 / 56$ & 43 & $3 \cdot 0 \star \star$ & $2 \cdot 3 \star \star$ \\
\hline$<15$ & $30 / 232$ & 17 & $1 \cdot 0$ & \\
\hline \multicolumn{5}{|l|}{$\operatorname{IgA}(\mathrm{mg} / \mathrm{dl})$} \\
\hline$>370$ & $18 / 54$ & 38 & $3 \cdot 1^{\star \star}$ & $3 \cdot 0^{\star \star}$ \\
\hline \multirow{2}{*}{\multicolumn{5}{|c|}{ Platelets $\left(\times 10^{9} / \mathrm{l}\right)$}} \\
\hline & & & & \\
\hline$<150$ & $12 / 40$ & 37 & $2 \cdot 5 \star \star$ & 1.6 \\
\hline$\geqslant 150$ & $38 / 248$ & 20 & $1 \cdot 0$ & \\
\hline \multicolumn{5}{|c|}{ Lymphadenopathy $(>2$ nodes $>1.0 \mathrm{~cm})$} \\
\hline Yes & $14 / 85$ & 26 & $1 \cdot 0$ & $1 \cdot 0$ \\
\hline No & $21 / 123$ & 21 & $1 \cdot 0$ & \\
\hline
\end{tabular}

${ }^{\star \star} \mathrm{p}<0.01 ;{ }^{\star} \mathrm{p}<0.05$

Note: Not all tests were carried out on all subjects so totals may not add up to 288 .

$26 \%, 70 \%$, and $100 \%$, respectively. A trichotomy of zero $v$ one $v$ two or more abnormalities was an effective discriminator of the probability of progressing to AIDS. Among the 111 men with no abnormalities none progressed to AIDS in the first 17 months of follow up, and overall five did (fig $2 d$ ). Two thirds of all men who progressed to AIDS either at 24 months or at 36 months were among the 68 with two or more abnormalities at baseline (fig $2 d$ ).

\section{CHANGE IN LABORATORY VALUES IN NON-PROGRESSORS}

The observed median number of T 4 cells in men who did not progress to AIDS fell from $626 \times 10^{6} / 1$ at baseline to $428 \times 10^{6} / 1$ (baseline adjusted estimate $376 \times 10^{6} / \mathrm{l}$ ) at the third follow up (fig 3). The proportion of men examined range on two or more predictive variables rose from $24 \%$ at baseline to $27 \%$, $33 \%$, and $41 \%$ at successive follow ups.

The overall proportion of men who remained free of AIDS and ARC and in the normal range on four or more predictors was $76 \%$ at baseline and $65 \%$, $50 \%$, and $35 \%$ at successive follow ups. Thus two thirds of the cohort had progressed to AIDS or ARC or to laboratory results that were highly predictive of AIDS or ARC at three years of follow up.

\section{PROJECTED SIX YEAR PROGRESSION RATE}

Projected progression rates at six years were calculated $(i)$ by applying the observed three year actuarial progression rates by number of laboratory abnormalities (fig $2 d$ ) to the distribution of laboratory values at the third 


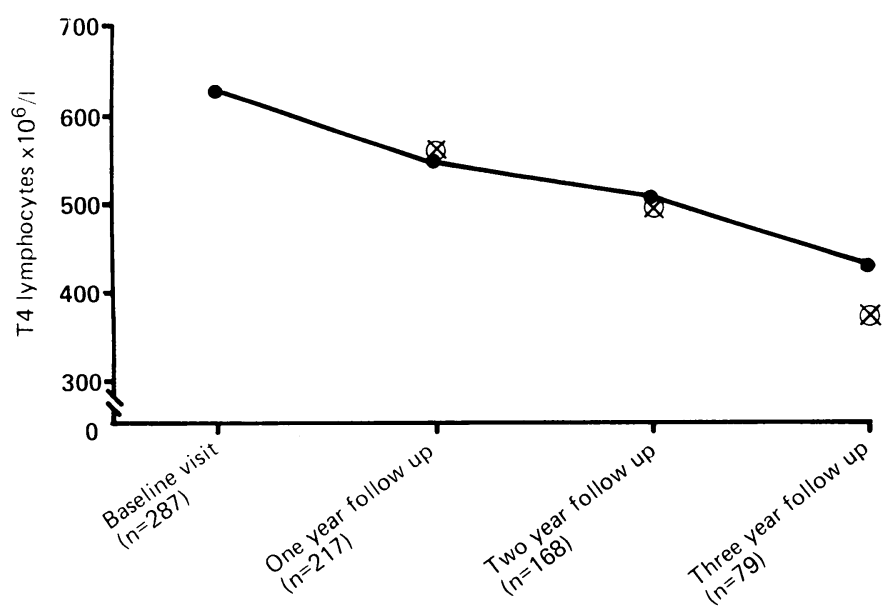

FIG 3-Median T4 lymphocytes $\times 10^{6} / 1$ at successive follow up examinations in subjects who were not progressing to AIDS. $=$ raw medians (observed values); $\otimes=$ median changes from baseline.

TABLE III-Baseline laboratory values predictive of AIDS, relative hazards, and $95 \%$ confidence intervals, stepwise Cox proportional hazards model $(n=280)$

\begin{tabular}{|c|c|c|}
\hline Variable & $\begin{array}{l}\text { Relative } \\
\text { hazard }\end{array}$ & $\begin{array}{c}95 \% \\
\text { Confidence intervals }\end{array}$ \\
\hline \multicolumn{3}{|l|}{$\beta_{2}$ Microglobulin (mg/1) } \\
\hline$>5.0$ & $7 \cdot 4^{\star \star}$ & $2 \cdot 8$ to $19 \cdot 4$ \\
\hline $3 \cdot 0-5 \cdot 0$ & $2 \cdot 6^{\star}$ & $1 \cdot 2$ to $5 \cdot 6$ \\
\hline$<3 \cdot 0$ & $1 \cdot 0$ & \\
\hline \multicolumn{3}{|l|}{ Packed cell volume } \\
\hline$<40$ & $3 \cdot 0^{\star \star}$ & 1.5 to 6.1 \\
\hline$\geqslant 40$ & $1 \cdot 0$ & \\
\hline \multicolumn{3}{|l|}{ HIV p 24 antigen } \\
\hline Yes & $2 \cdot 5^{\star \star}$ & $1 \cdot 3$ to 4.9 \\
\hline No & $1 \cdot 0$ & \\
\hline \multicolumn{3}{|c|}{ Proportion of lymphocytes that were T4 cells (\%) } \\
\hline$<25$ & $2 \cdot 5^{\star \star}$ & $1 \cdot 3$ to $4 \cdot 8$ \\
\hline$\geqslant 25$ & $1 \cdot 0$ & \\
\hline \multicolumn{3}{|l|}{ T4 lymphocyte count $\times 10^{6} / 1$} \\
\hline$\leqslant 200$ & $2 \cdot 9^{\star}$ & $1 \cdot 1$ to $7 \cdot 4$ \\
\hline$>200$ & $1 \cdot 0$ & \\
\hline
\end{tabular}

$\star \star \mathrm{p}<0.01 ;{ }^{\star} \mathrm{p}<0.05$.

Note: One or more values are missing for eight subjects.

follow up and (ii) by extrapolating the one year progression rate in the most recent year of follow up for three more years. The two methods predict $49 \%$ and $52 \%$ progression rates to AIDS respectively at six years of study and $75 \%$ and $79 \%$ to AIDS or ARC. These estimates are conservative because ARC is underestimated by the follow up assumption (see Methods), and AIDS is underestimated by late reporting and because subjects with symptoms were excluded at baseline. The apparent acceleration in progression rate, rate of antigen development, and proportion moving to abnormal T4 lymphocyte counts also suggest that the projections are conservative. Men who did not return for laboratory follow up after baseline examination were slightly more likely to progress than those who were seen for follow up but the difference was not significant $(\mathrm{RH}=1.4, \mathrm{p}=0.45)$. Thus projections based on those seen at follow up are more likely to underestimate than overestimate progression.

\section{COFACTORS FOR PROGRESSION}

Of the variables we studied, only the age of the subject was a significant cofactor for progression. Men who were 35 or over had a relative hazard of $2 \cdot 1(p=0.015)$ when compared with men under 35. Prior exposure to venereal disease, sexual activity, and having had sex with a person with AIDS were not associated with progression. The crude progression rates in groups 1,2 , and 3 were $16 \%, 16 \%$, and $19 \%$ respectively $(p=0.46)$, thus group did not appear to be a cofactor. Median T4 lymphocyte counts in the three groups at baseline were 675,626 , and 619 respectively, suggesting similar median dates of infection.

\section{Discussion}

The actuarial progression rates at three years in the San Francisco
General Hospital study were $22 \%$ to AIDS and an additional $19 \%$ to ARC.

From the dates given on stored sera the median date of infection in the widely reported San Francisco City Clinic cohort was determined as mid-1981 (N Hessol et al). ${ }^{13}$ That cohort, recruited in the San Francisco clinic for sexually transmitted diseases, corresponds closely to group 2 in our study. Progression rates and baseline median T4 lymphocyte counts suggest that the seropositive subjects in groups 1,2, and 3 in our study have similar median dates of infection. Thus it is likely that the median date of infection for the original cohort as a whole was about mid-1981, or three years before the median date of entry to the study. The current progression rate to AIDS of $22 \%$ may thus approximate the actuarial rate at about six years after infection. This result is consistent with those of Goedert et $a l$ and Eyster $e t a l^{+6}$ and with the San Francisco City Clinic cohort (N Hessol et al)..$^{13}$ These studies are consistent with the Multicenter AIDS Cohort Study if that cohort was infected some one to two years later than the two San Francisco cohorts.

In a multivariate analysis of progression to AIDS we found independent predictive effects associated with $(i) \beta_{2}$ microglobulin concentration, (ii) packed cell volume, (iii) HIV p24 antigenaemia, (iv) proportion of T4 lymphocytes, and ( $v$ ) absolute number of T4 lymphocytes. This set of variables was both a good discriminator between seropositive and seronegative men-99\% of the latter being normal on four or more variables-and a very good predictor of progression to AIDS. Of seropositive men who were normal on all five variables, none progressed before 17 months. On the other hand, two thirds of all men in whom AIDS was diagnosed either at two years or at three years were in the relatively small group who were abnormal on two or more variables at baseline.

$\beta_{2}$ Microglobulin concentration was the best single predictor of progression. This is a low molecular weight protein that is present on the surface of all nucleated cells as the constant subunit of the class I histocompatibility antigens. ${ }^{14}$ It is produced at a relatively constant rate in healthy subjects and is released into body fluids as a result of cell turnover. The production and turnover rate are increased in both cytomegalovirus infection and HIV infection. ${ }^{1516}$ The high concentration of $\beta_{2}$ microglobulin observed in men who are progressing rapidly to AIDS may be a direct measure of activation in target cell populations of HIV infection (T4 lymphocytes, macrophages), or it may reflect reactivated cytomegalovirus infection, which is common in pre-AIDS patients. Serum $\beta_{2}$ microglobulin may be a better predictor of progression than the T4 lymphocyte count because it reflects macrophage activation as well as lymphocyte activation or perhaps because it reflects target cell activation in all tissues and not in the peripheral circulation alone. The presence of p24 antigen was also a good indicator of progression, comparable with $\mathrm{T} 4$ dichotomised at $400 \times 10^{6} / 1$ as a single predictor. Since both $\beta_{2}$ microglobulin and p24 assays are available in EIA kits, our study suggests that good prognostic information can be obtained without counting lymphocyte subsets. In clinical trials of HIV infected people with no symptoms the combination of $\beta_{2}$ microglobulin and p24 levels with T4 lymphocyte counts will identify much larger groups at high risk than lymphocyte counts alone.

The most striking feature of our study was the change in the seropositive subjects who had not yet progressed to AIDS. There was a progressive loss of the T4 lymphocyte subpopulation, the baseline adjusted median T4 lymphocyte count falling about 85 cells $\times 10^{6} / 1$ per year. There were increases in the proportions that were abnormal on all predictive variables. Clearly, the subjects who have progressed to AIDS do not represent a simple selecting out of a subgroup at risk, leaving the rest of the cohort unaffected. On the contrary, the prognosis for the rest of the cohort is worsening over time, two thirds showing AIDS or ARC or laboratory results that are highly predictive of AIDS at the third year of the study. From the declining values in the laboratory results and under conservative assumptions the course of the study can be predicted for the next three years. Half of the seropositive subjects are predicted to progress to AIDS by six years of follow up, or probably nine years from infection, and three quarters are predicted to progress to AIDS or ARC. Furthermore, since ARC as defined here is highly 

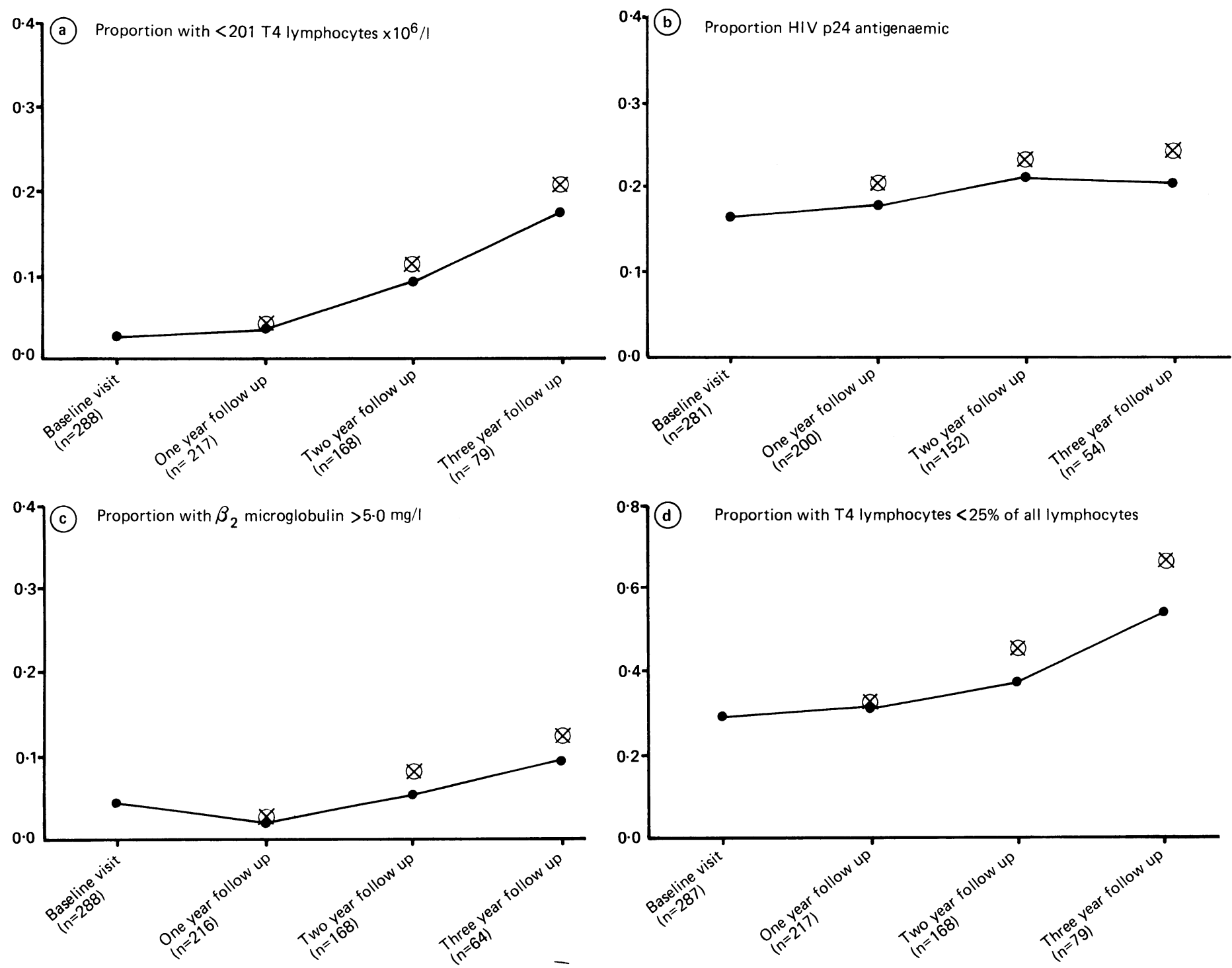

FIG 4-Abnormal laboratory results at successive follow up examinations in subjects who did not progress to AIDS. (a) Proportion with T4 lymphocytes $\leqslant 200 \times 10^{6} / 1$. (b) Proportion with HIV p 24 antigen. $(c)$ Proportion with $\beta_{2}$ microglobulin $>5.0 \mathrm{mg} / \mathrm{l}$. (d) Proportion with T4 lymphocytes $<25 \%$ of all lymphocytes. $Q=$ raw proportions (observed values); $\otimes=$ baseline adjusted proportions.

predictive of AIDS and as additional subjects will have progressed to abnormal laboratory results without ARC by six years our results suggest that at least three quarters of the seropositive people in the cohort will eventually develop AIDS. These results and recent successes with treatment with azidothymidine strongly support extending clinical trials to include seropositive subjects without symptoms. And the results suggest that in considering the importance of AIDS prevention we should regard progression to clinical AIDS after infection with HIV as the norm rather than the exception.

We thank the men who made this study possible by participating in it; Rita Meakin, Elliot Ross, and James Halsey for long and effective service; Eileen O'Connell; Dr Paul Volberding and the staff of the AIDS clinic at San Francisco General Hospital; Dr Michael Leuther, Abbott Laboratories; Dr John Greenspan and the staff of the AIDS serum bank at UCSF; and Dr Herbert Perkins, Irwin Memorial Blood Bank.

This work was supported by funds provided by the State of California and allocated on the recommendation of the Universitywide Task Force on AIDS.

\section{References}

1 Centers for Disease Control (CDC). Kaposi's sarcoma and pneumocystis pneumonia among homosexual men—New York City and California. MMWR 1981;30:305-8.
2 Barre-Sinoussi F, Chermann J-C, Rey F, et al. Isolation of a T-lymphotropic retrovirus from a patient at risk for acquired immune deficiency syndrome (AIDS). Science 1983;220:868-71. 3 Gallo RC, Salahuddin SZ, Popovic M, et al. Frequent detection and isolation of cytopathic retroviruses (HTLV-III) from patients with AIDS and at risk from AIDS. Science 1984;224 500-3.

4 Goedert J, Biggar R, Weiss S, et al. Three year incidence of AIDS in five cohorts of HTLV-III infected risk group members. Science 1986;231:992-5.

5 Polk BF, Fox R, Brookmeyer R, et al. Predictors of the acquired immunodeficiency syndrome developing in a cohort of seropositive homosexual men. N Engl f Med 1987;316:61-6.

6 Eyster ME, Gail MH, Ballard JO, et al. Natural history of immunodeficiency virus infection in hemophiliacs: effects of T-cell subsets, platelet counts and age. Ann Intern Med 1987;107:1.

7 Carlson J, Bryant $M$, Hinrich S, et al. AIDS serology testing in low- and high-risk groups. FAMA 1985;253:3405-8

8 Allain J-P, Paul D, Laurian Y, et al. Serological markers in early stages of human immunodeficiency virus infection in haemophiliacs. Lancet 1986;ii:1232-6.

9 Stites D, Casavant C, McHugh T, et al. Flow cytometric analysis of lymphocyte phenotypes in AIDS using monoclonal antibodies and simultaneous dual immunofluorescence. Clin Immuno Immunopathol 1986;38:161-77.

10 Redfield RR, Wright DC, Tramont EC. The Walter Reed staging classification for HTLVIII/LAV infection. $N$ Engl f Med 1986;314:131-2.

11 Centers for Disease Control. Revision of the case definition of acquired immunodeficiency syndrome for national reporting-United States. MMWR 1985;34:373-5.

12 Cox DR, Oakes D. Analysis of survival data. London: Chapman and Hall, 1984.

13 Jaffe HW, Darrow WD, Echenberg D, et al. The acquired immunodeficiency syndrome in cohort of homosexual men. Ann Intern Med 1985;103:210-4.

14 Berggard I, Bearn AG. Isolation and properties of a low molecular weight microglobulin occurring in human biological fluids. $\mathcal{f}$ Biol Chem 1968;243:4095-5103.

15 Karlsson FA, Wibell L, Evrin PE. Beta 2 microglobulin in clinical medicine. Scand $\mathcal{J}$ Clin Lab Invest 1980;40 (suppl 154):27-37.

16 Zolla-Pagner S, William D, El-Sadr W, Marmor M, Stahl R. Quantitation of $\mathrm{B}_{2}$-microglobulin and other immune characteristics in a prospective study of men at risk for acquired immune deficiency syndrome. FAMA 1984;251:2951-5.

(Accepted 19 November 1987 ) 